\title{
Elevated C-peptide and insulin predict increased risk of colorectal adenomas in normal mucosa
}

\author{
Adriana C Vidal', Pauline Kay Lund ${ }^{2,3}$, Cathrine Hoyo ${ }^{1}$, Joseph Galanko ${ }^{2}$, Lauren Burcal ${ }^{2}$, Rachel Holston², \\ Berri Massa², Oluwaseun Omofoye ${ }^{2}$, Robert S Sandler ${ }^{2}$ and Temitope O Keku²
}

\begin{abstract}
Background: Lower concentrations of the insulin-like growth factor binding protein-1 (IGFBP-1) and elevated concentrations of insulin or C-peptide have been associated with an increase in colorectal cancer risk (CRC). However few studies have evaluated IGFBP-1 and C-peptide in relation to adenomatous polyps, the only known precursor for CRC.

Methods: Between November 2001 and December 2002, we examined associations between circulating concentrations of insulin, C-peptide, IGFBP-1 and apoptosis among 190 individuals with one or more adenomatous polyps and 488 with no adenomatous polyps using logistic regression models.

Results: Individuals with the highest concentrations of C-peptide were more likely to have adenomas (OR $=2.2$, $95 \% \mathrm{Cl} 1.4-4.0)$ than those with the lowest concentrations; associations that appeared to be stronger in men $(\mathrm{OR}=4.4,95 \% \mathrm{Cl}$ 1.7-10.9) than women. Individuals with high insulin concentrations also had a higher risk of adenomas (OR $=3.5,95 \% \mathrm{Cl} 1.7-7.4)$, whereas higher levels of IGFBP-1 were associated with a reduced risk of adenomas in men only $(\mathrm{OR}=0.3,95 \% \mathrm{Cl} 0.1-0.7)$. Overweight and obese individuals with higher C-peptide levels $\left(>1^{\text {st }} \mathrm{Q}\right)$ were at increased risk for lower apoptosis index $(\mathrm{OR}=2.5,95 \% \mathrm{Cl}$ 0.9-7.1), an association that remained strong in overweight and obese men ( $\mathrm{OR}=6.3,95 \% \mathrm{Cl}$ 1.0-36.7). Higher levels of IGFBP-1 in overweight and obese individuals were associated with a reduced risk of low apoptosis ( $\mathrm{OR}=0.3,95 \% \mathrm{Cl} 0.1-1.0)$.

Conclusions: Associations between these peptides and the apoptosis index in overweight and obese individuals, suggest that the mechanism by which C-peptide could induce adenomas may include its anti-apoptotic properties. This study suggests that hyperinsulinemia and IGF hormones predict adenoma risk, and that outcomes associated with colorectal carcinogenesis maybe modified by gender.
\end{abstract}

Keywords: Insulin, C-peptide, Insulin-like growth factor binding protein

\section{Background}

Colorectal adenomas are precursors to colorectal cancer (CRC) [1], and CRC is the second most common cancer in men and women worldwide [2]. Reducing CRC risk will depend on identification of potential markers of precancerous adenomas. Components of the insulin-IGF axis have been key targets to identify potential biomarkers of adenoma risk, in part because western diets, physical inactivity and other factors associated with obesity, insulin resistance and diabetes history, are known risk factors for colon

\footnotetext{
* Correspondence: tokeku@med.unc.edu

${ }^{2}$ Department of Medicine and Center for Gastrointestinal Biology \& Disease School of Medicine, University of North Carolina, Chapel Hill, North Carolina Full list of author information is available at the end of the article
}

cancer [3]. The mechanisms by which obesity and insulin resistance promote CRC are not well understood, although insulin is a crucial component in the regulation of energy metabolism. Elevated circulating insulin levels have also been associated with mitogenic $[4,5]$ and anti-apoptotic effects in overweight and obese individuals [6]. Thus, higher circulating insulin levels may promote colorectal adenomas and cancer through increased proliferation or reduced apoptosis $[5,7]$.

Insulin, insulin growth factor I (IGF-I) and IGF-II are structurally related proteins that share common receptors [8]. At high concentrations, insulin may utilize insulin receptors (IR), IGF1 receptors (IGF1R) or hybrid IR/ IGF1R to regulate cell proliferation and apoptosis [9-11].

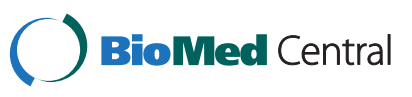


Insulin can also act directly to promote IGF-I biosynthesis or can enhance IGF-I bioavailability by inhibiting the production of IGF-binding proteins (IGFBP) such as IGFBP-1 [12,13]. IGFBP-1 plays an important role in glucose homeostasis, and circulating IGFBP-1 is inversely related to C-peptide and insulin levels $[14,15]$. Furthermore, IGFBP-1 can also induce apoptosis in breast and prostate cancer cells in vitro as well as suppress tumor growth in an insulin dependent and independent manner [16]. Thus, IGFBP-1 levels may influence colorectal adenomas and cancer development via two mechanisms: inhibition of the proliferative actions of insulin and IGF, and promotion of apoptosis. Disentangling these relationships will be important in determining the utility of these peptide hormones as disease markers.

We have previously reported a positive association between elevated fasting plasma insulin levels and adenomas in the Diet and Health Study III [17]. More recently, we observed that local expression of IGFBP-3 was inversely related to adenomas [18]. Based on these previous observations, we hypothesized that elevated IGFBP-1 is associated with reduced risk of adenomas and low apoptosis in normal mucosa. Few studies have evaluated IGFBP-1 and C-peptide or insulin in relation to colorectal adenomas and cancer and the results are inconsistent [19-24]. Inconsistencies may be due in part to differences in race/ethnicity [22] and gender [24]. Moreover, the relationships between these markers and apoptosis have not, to our knowledge, been addressed [17]. The aim of this study was to determine the associations of IGFBP-1, insulin, and C-peptide (a surrogate biomarker of pancreatic insulin secretion), with colorectal adenoma (adenomatous polyps) in the Diet and Health study IV, in a majority White cohort and whether these associations vary by gender.

\section{Methods \\ Study population}

Study participants in the Diet and Health Study IV were drawn from outpatients who underwent screening colonoscopy between November 2001 and December 2002 at the University of North Carolina hospitals (Chapel Hill, NC). Eligible subjects provided informed consent and agreed to participate in a telephone interview, give rectal biopsies or have blood drawn. Subjects were excluded for the following reasons, incomplete examination (cecum not reached), age $<30$ years, inability to give informed consent, polyposis ( $>100$ polyps), previous colon resection or cancer, colitis, and previous colon adenoma. All histology and classification of colon polyps in the study were performed as previously described [17]. Advanced adenoma was defined as having an adenoma at least $1 \mathrm{~cm}$ in diameter, histology of villoglandular or villous or severe atypia. Individuals who had one or more adenomatous polyps were defined as cases while control subjects had no adenomatous polyps. The study was approved by the School of Medicine institutional review board at the University of North Carolina.

\section{Data collection}

The data collection was similar to previous protocols $[17,25,26]$. Briefly, eligible and consenting participants provided information about the time of last meal, (to confirm an overnight fast) and the type of colonoscopy preparation used. We also measured height, body weight, and waist and hip circumference. A total of 1027 subjects were eligible, 123 (12\%) refused to participate, 91 (9\%) were not asked because the research assistant was not available, and an additional $107(10 \%)$ patients were classified as ineligible after the colonoscopy due to incomplete or unsatisfactory preparation. The study was completed by 701 individuals, with a response rate of 76\% (number interviewed/number eligible). Complete information on insulin, C-peptide, IGFBP-1, adenomas and apoptosis was available for 678 subjects. Enrolled subjects completed telephone interviews about diet and lifestyle within 12 weeks of colonoscopy. The lifestyle questionnaire was used to collect data about demographics, family history, education, medical history, physical activity, and other environmental factors. Dietary information was collected using the NCI Diet History food frequency questionnaire that queried foods and usual portion size (small, medium, or large) consumed [27].

\section{Biological specimens and laboratory assays}

Specimens' preparation and handling have been previously described [8]. Subjects used either a balanced electrolyte polyethylene glycol lavage or a phosphate-containing purge prep prior to colonoscopy. At the beginning of the endoscopic procedure, six mucosal pinch biopsies were obtained 8 to $10 \mathrm{~cm}$ from the anal verge using standard disposable, fenestrated colonoscopy forceps (Wilson-Cook, Winston-Salem, NC). The same site was sampled in all subjects. Blood samples were obtained prior to administration of medication through an i. v. catheter and processed within 2-6 hours in the lab. Samples were kept at $4^{\circ} \mathrm{C}$ prior to processing. Plasma from the blood samples was stored in aliquots at $-80^{\circ} \mathrm{C}$ until assayed. Care was taken to avoid repeated freezing and thawing of samples. We analyzed samples from patients with excellent colonoscopy preparation and confirmed overnight fast (based on verbal response about last food intake and supportive evidence of a clean colon). Circulating insulin, C-peptide and IGFBP-1 levels were measured by ELISA using reagents from Diagnostic Systems Laboratory (Webster, TX). Laboratory personnel were blinded to the case or 
control status of samples. The intra-assay coefficient of variation was $2.6 \%$ for insulin, $4.2 \%$ for C-peptide and $5.1 \%$ for IGFBP-1. The inter-assay coefficient of variation was $<12 \%$ for insulin, C-peptide and IGFBP-1 measures.

\section{Assays of apoptosis}

Colonic biopsies were fixed in 10\% buffered formalin and processed by routine histology. Apoptosis was scored by personnel who were trained by study pathologist to differentiate between apoptosis and necrosis. A subset of slides was re-scored by a second trained scorer (TOK) in a blinded fashion. The inter-rater level of agreement was $>94 \%$. We chose to use morphology to assess apoptosis in this study based on our previous experience. Previously, we have used two methods, morphology and TUNEL to assess apoptosis and found a high level of correlation between the two methods $(r=0.73$, $\mathrm{p}=0.01)$ [17].

\section{Statistical analysis}

Comparison of continuous and categorical variables between adenoma cases and non-adenoma controls were made using $\mathrm{t}$ tests and Chi square tests, respectively. The relationships between plasma insulin, C-peptide, IGFBP-1 and colorectal adenomas were assessed in the study population by comparing mean values between case and control subjects using $\mathrm{t}$ tests. The distribution of insulin, C-peptide, IGFBP-1 measures among control subjects was used to generate quartile values. The lowest quartile of each measure was considered as the reference. Apoptosis was expressed as the average number of apoptotic cells per crypt. Using the median as cut point, we divided apoptosis measures into lower half (below the median) and upper half (above the median). Logistic regression models were used to examine the association between adenoma status and insulin, C-peptide, IGFBP1 or apoptosis. Confounder candidates for inclusion in the model were age, race, sex, BMI, family history, total fat intake, alcohol intake, waist to hip ratio, diabetes history, smoking status, NSAID use, calcium intake and red meat intake. Each of these was added to a model containing the main variable of interest (in quartiles) and if at least two of the quartile parameter estimates changed by more than $10 \%$ then the variable was considered a potential confounder. All variables that met that standard were then entered into a backwards stepwise procedure with the main variable of interest being forced into the model.

In addition, we also performed the trend test to examine for linear increase over quartile 1 to quartile 4 (p-trend). The relationships between insulin, C-peptide, IGFBP-1 and BMI, and waist-to hip ratio (WHR) were assessed by the Spearman correlation coefficient. In cases, we also measured Spearman correlation coefficients between number and size of adenomas and C-peptide, insulin and IGFBP-1 levels.

\section{Results}

The characteristics of study participants are shown in Table 1. Compared to controls (mean BMI $=27.1$ se $=0.3$ ), cases were significantly more likely to have higher BMI (mean BMI = 28.3 se $=0.4$ ), and increased waist-hip ratio (WHR), mean WHR $=0.88(\mathrm{se}=0.01) v s$. mean WHR $=0.93(\mathrm{se}=0.01)$. A higher proportion of cases reported increased consumption of alcohol and red meat intake $($ mean $=1.7 \mathrm{svgs} /$ day se $=0.11)$ than controls $($ mean $=1.47$ svgs $/$ day se $=0.06)$. Apoptosis was also significantly lower in cases than controls $(\mathrm{p}=0.0003)$ while the mean levels of circulating $C$-peptide $(p=0.05)$ and insulin ( $p=0.008$ ) were significantly elevated in cases than controls (Figure 1). Mean plasma IGFBP-1 was lower in cases than controls but the results did not reach statistical significance (Figure 1).

Table 2 summarizes the associations between plasma insulin, C-peptide, IGFBP-1 and adenomas. Overall, elevated $\mathrm{C}$-peptide or insulin showed a positive association with adenomas ( $\mathrm{p}$-trend $\leq 0.01$ ). Compared to those with the lowest quartile (Q1) of plasma insulin or C-peptide

Table 1 Descriptive characteristics of adenoma cases and adenoma-free controls

\begin{tabular}{|c|c|c|c|}
\hline Variable & $\begin{array}{c}\text { Cases } \\
(\mathrm{N}=190)\end{array}$ & $\begin{array}{l}\text { Controls } \\
(N=488)\end{array}$ & p-value \\
\hline Mean Age in Years (SE) & $56.8(0.7)$ & $55.7(0.5)$ & 0.19 \\
\hline White (\%) & $156(82)$ & $383(78)$ & 0.34 \\
\hline Male (\%) & $112(59)$ & $188(39)$ & 0.0001 \\
\hline Mean Body Mass Index (SE) & $28.3(0.4)$ & $27.1(0.3)$ & 0.02 \\
\hline Family History of CRC (\%) & $28(17)$ & $60(14)$ & 0.37 \\
\hline Mean Dietary Fat (g/day) (SE) & $70.8(2.7)$ & $68.6(1.5)$ & 0.47 \\
\hline Mean Alcohol ${ }^{1}$ (SE) & $12.6(1.7)$ & $8.2(0.7)$ & 0.02 \\
\hline Mean Waist/hip Ratio (SE) & $0.930(0.008)$ & $0.886(0.007)$ & 0.0001 \\
\hline Smokers (\%) & $29(17)$ & 49 (11) & 0.06 \\
\hline $\begin{array}{l}\text { Mean Monthly NSAID Use in } \\
\text { Past } 5 \text { Years (SE) }\end{array}$ & $12.9(2.0)$ & $12.7(1.4)$ & 0.94 \\
\hline Mean Total Daily Calcium (mg) (SE) & $744(28)$ & $785(18)$ & 0.23 \\
\hline Mean Red Meat (svgs/day) (SE) & $1.73(0.11)$ & $1.47(0.06)$ & 0.03 \\
\hline Apoptosis (Morphology)² & $3.33(0.10)$ & $3.76(0.06)$ & 0.0003 \\
\hline C-peptide (mean, se) & $1.86(0.10)$ & $1.61(0.08)$ & 0.05 \\
\hline IGFBP-1 (mean, se) & $21.3(1.60)$ & $24.1(1.02)$ & 0.13 \\
\hline Insulin (mean, se) & $10.5(0.8)$ & $8.1(0.5)$ & 0.008 \\
\hline Number of Adenomas (mean, se) & $1.58(0.08)$ & - & - \\
\hline Adenoma size (mean, se) ${ }^{3}$ & $6.21(0.45)$ & - & \\
\hline
\end{tabular}

${ }^{1}$ Daily grams from alcohol.

${ }^{2}$ Apoptosis - mean apoptotic cells per crypt.

${ }^{3}$ Mean size of the largest adenoma. 

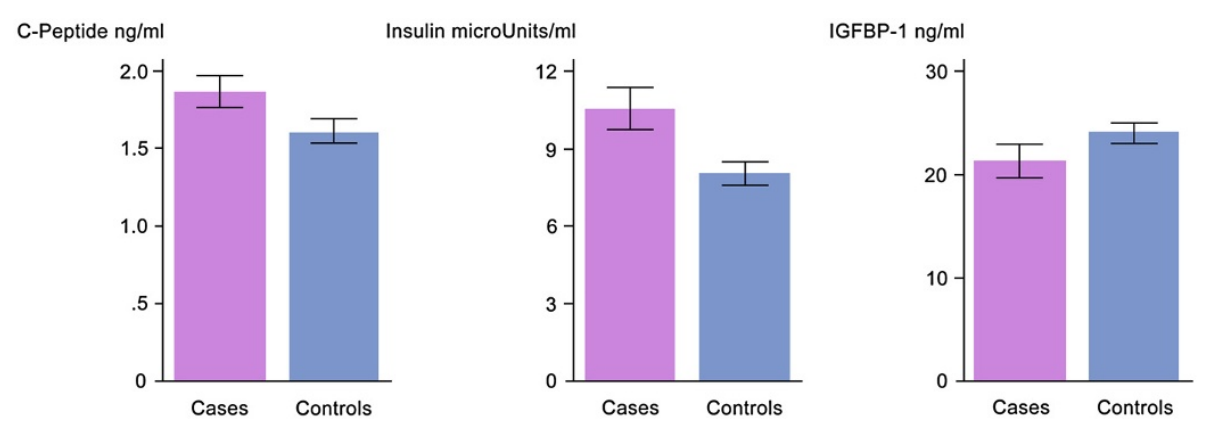

Figure 1 Mean levels of circulating C-peptide, insulin and IGFBP-1 in adenoma cases and non-adenoma controls. C-peptide ( $p=0.05)$ and insulin $(p=0.008$ ) levels were significantly elevated in cases compared to controls. Mean plasma IGFBP-1 was lower in cases than in controls but the results did not reach statistical significance.

levels, levels of these analytes in the fourth quartile (Q4) were associated with a 2 to 5 -fold increased risk of adenomas $(\mathrm{OR}=3.5,95 \% \mathrm{CI} 1.7-7.4, \mathrm{p}$-trend $=0.002$, $\mathrm{OR}=2.2,95 \%$ CI 1.2-4.0, p-trend $=0.04$, respectively). For $\mathrm{C}$-peptide these associations may be stronger in men (Q4 $\mathrm{OR}=4.4,95 \%$ CI $1.7-10.9$, $\mathrm{p}$-trend $=0.006$ ), than women $(\mathrm{OR}=1.6,95 \%$ CI $0.7-4.0$, p-trend $=0.58)$. Overall, associations were stronger in the $3^{\text {rd }}$ and $4^{\text {th }} \mathrm{Q}$, for both Cpeptide and insulin (Table 2). On the other hand, we found a statistically significant association between higher levels of IGFBP-1 and reduced risk for adenoma in men $(\mathrm{OR}=0.3,95 \%$ CI $0.1-0.7$, p-trend $=0.0007)$. These associations remained unaltered after excluding BMI and WHR from the statistical models.

We examined the relationship between apoptosis levels and C-peptide, insulin and IGFBP1 in males and females. We found no evidence for associations between levels of C-peptide, insulin and IGFBP-1, and the apoptosis index, among all individuals. However, restricting analyses for overweight and obese individuals, we found that higher C-peptide levels $\left(>1^{\text {st }} \mathrm{Q}\right)$ were associated with increased risk of lower apoptosis index $(\mathrm{OR}=2.5,95 \% \mathrm{CI}$ 0.9-7.1, ptrend $=0.048)$, an association that persisted in men $(\mathrm{OR}=6.3,95 \%$ CI 1.0-36.7, p-trend $=0.04)($ Table 3$)$.

Table $2 *$ Adjusted ORs and $95 \% \mathrm{Cl}$ for the relationship between the C-peptide, IGFBP-1 and adenoma status, overall, and among men and women

\begin{tabular}{|c|c|c|c|c|c|c|}
\hline \multirow[b]{2}{*}{ Measure } & \multicolumn{2}{|r|}{ Overall } & \multicolumn{2}{|r|}{ Men } & \multicolumn{2}{|r|}{ Women } \\
\hline & Case/control (n) & Adjusted $\mathrm{OR}^{1}(95 \% \mathrm{Cl})$ & Case/control (n) & Adjusted OR ${ }^{1}(95 \% \mathrm{Cl})$ & Case/control (n) & Adjusted $\mathrm{OR}^{1}(95 \% \mathrm{Cl})$ \\
\hline \multicolumn{7}{|l|}{ C-Peptide } \\
\hline Quartile 1 & $29 / 106$ & 1.0 (Referent) & $14 / 40$ & 1.0 (Referent) & $15 / 66$ & 1.0 (Referent) \\
\hline Quartile 2 & $32 / 108$ & $1.2(0.6,2.1)$ & $19 / 42$ & $1.9(0.7,4.8)$ & $13 / 66$ & $0.8(0.3,2.1)$ \\
\hline Quartile 3 & $40 / 101$ & $1.4(0.8,2.6)$ & $24 / 40$ & $2.6(1.0,6.9)$ & $16 / 61$ & $1.0(0.4,2.4)$ \\
\hline Quartile 4 & $71 / 105$ & $2.2(1.2,4.0)$ & $48 / 45$ & $4.4(1.7,10.9)$ & $23 / 60$ & $1.6(0.7,4.0)$ \\
\hline$P$ trend & & 0.04 & & 0.006 & & 0.58 \\
\hline \multicolumn{7}{|l|}{ IGFBP-1 } \\
\hline Quartile 1 & $51 / 106$ & 1.0 (Referent) & $36 / 41$ & 1.0 (Referent) & $15 / 65$ & 1.0 (Referent) \\
\hline Quartile 2 & $52 / 103$ & $0.9(0.5,1.6)$ & $35 / 49$ & $0.7(0.3,1.5)$ & $17 / 54$ & $1.2(0.5,3.0)$ \\
\hline Quartile 3 & $37 / 105$ & $0.7(0.4,1.2)$ & $22 / 42$ & $0.5(0.2,1.0)$ & $15 / 63$ & $1.3(0.5,3.1)$ \\
\hline Quartile 4 & 29/105 & $0.6(0.3,1.1)$ & $10 / 35$ & $0.3(0.1,0.7)$ & 19/70 & $1.4(0.6,3.4)$ \\
\hline$P$ trend & & 0.13 & & 0.007 & & 0.47 \\
\hline \multicolumn{7}{|l|}{ Insulin } \\
\hline Quartile 1 & $21 / 88$ & 1.0 (Referent) & $14 / 37$ & 1.0 (Referent) & $7 / 51$ & 1.0 (Referent) \\
\hline Quartile 2 & $27 / 84$ & $1.7(0.8,3.7)$ & $17 / 32$ & $1.3(0.5,3.5)$ & $10 / 52$ & $2.6(0.7,9.0)$ \\
\hline Quartile 3 & $40 / 81$ & $2.6(1.2,5.5)$ & $29 / 31$ & $3.1(1.2,7.9)$ & $11 / 50$ & $2.4(0.7,8.6)$ \\
\hline Quartile 4 & $55 / 84$ & $3.5(1.7,7.4)$ & $31 / 33$ & $2.8(1.1,7.1)$ & $24 / 51$ & $4.6(1.5,15.3)$ \\
\hline $\mathrm{P}$ trend & & 0.002 & & 0.02 & & 0.03 \\
\hline
\end{tabular}

*Adjusted for race, sex, BMI, WHR, diabetes history, alcohol intake, smoking and red meat intake. 
Table 3 *Adjusted ORs and $95 \% \mathrm{Cl}$ for the relationship between the C-peptide, IGFBP-1 and low apoptosis, among overweight and obese individuals (BMI > 30)

\begin{tabular}{|c|c|c|c|c|c|c|}
\hline \multirow[b]{2}{*}{ Measure } & \multicolumn{2}{|l|}{ Overall } & \multicolumn{2}{|l|}{ Men } & \multicolumn{2}{|l|}{ Women } \\
\hline & $\frac{\text { Apoptosis (n, Lower/ }}{\text { upper half) }}$ & $\begin{array}{c}\text { Adjusted } \\
\text { OR }^{1}(95 \% \mathrm{Cl})\end{array}$ & $\frac{\text { Apoptosis (n, Lower/ }}{\text { upper half) }}$ & $\begin{array}{c}\text { Adjusted } \\
\mathrm{OR}^{1}(95 \% \mathrm{Cl})\end{array}$ & $\frac{\text { Apoptosis (n, Lower/ }}{\text { upper half) }}$ & $\begin{array}{c}\text { Adjusted } \\
\text { OR }^{1}(95 \% \mathrm{Cl})\end{array}$ \\
\hline \multicolumn{7}{|l|}{ C-Peptide } \\
\hline Quartile 1 & $12 / 16$ & 1.0 (Referent) & $6 / 7$ & 1.0 (Referent) & $6 / 9$ & 1.0 (Referent) \\
\hline Quartile 2 & $26 / 20$ & $3.1(1.0,9.5)$ & $9 / 11$ & $4.4(0.7,30.0)$ & $17 / 9$ & $3.9(0.9,16.1)$ \\
\hline Quartile 3 & $33 / 24$ & $2.7(0.9,8.1)$ & $17 / 9$ & $7.0(1.1,45.3)$ & $16 / 15$ & $1.9(0.5,7.3)$ \\
\hline Quartile 4 & $54 / 45$ & $2.5(0.9,7.1)$ & $30 / 21$ & $6.3(1.1,36.7)$ & $24 / 24$ & $1.5(0.4,5.5)$ \\
\hline$P$ trend & & 0.0465 & & 0.04 & & 0.30 \\
\hline \multicolumn{7}{|l|}{ IGFBP-1 } \\
\hline Quartile 1 & $51 / 35$ & 1.0 (Referent) & $24 / 13$ & 1.0 (Referent) & $27 / 22$ & 1.0 (Referent) \\
\hline Quartile 2 & $44 / 33$ & $0.9(0.5,1.9)$ & $23 / 16$ & $0.9(0.3,2.6)$ & $21 / 17$ & $1.0(0.4,2.5)$ \\
\hline Quartile 3 & $22 / 19$ & $0.9(0.4,2.1)$ & $12 / 12$ & $0.5(0.1,1.6)$ & $10 / 7$ & $1.4(0.4,4.9)$ \\
\hline Quartile 4 & $8 / 18$ & $0.3(0.1,1.0)$ & $3 / 7$ & $0.2(0.03,1.2)$ & $5 / 11$ & $0.4(0.1,1.5)$ \\
\hline$P$ trend & & 0.10 & & 0.07 & & 0.44 \\
\hline \multicolumn{7}{|l|}{ Insulin } \\
\hline Quartile 1 & $11 / 14$ & 1.0 (Referent) & $6 / 8$ & 1.0 (Referent) & $5 / 6$ & 1.0 (Referent) \\
\hline Quartile 2 & $25 / 17$ & $1.6(0.5,5.1)$ & $16 / 5$ & $2.3(0.4,13.1)$ & $9 / 12$ & $1.1(0.2,5.5)$ \\
\hline Quartile 3 & $33 / 25$ & $1.3(0.4,3.9)$ & $17 / 13$ & $0.7(0.1,3.4)$ & $16 / 12$ & $1.7(0.3,8.5)$ \\
\hline Quartile 4 & $40 / 32$ & $1.5(0.5,4.4)$ & $17 / 10$ & $1.0(0.2,4.9)$ & $23 / 22$ & $1.6(0.4,7.1)$ \\
\hline$P$ trend & & 0.46 & & 0.99 & & 0.53 \\
\hline
\end{tabular}

*Adjusted for race, sex, alcohol intake, diabetes history, smoking and red meat intake.

Whereas higher levels of IGFB-1 in overweight and obese individuals overall were associated with a reduced risk of low apoptosis $(\mathrm{OR}=0.3,95 \% \mathrm{CI} 0.1-1.0$, p-trend $=0.10)$ (Table 3). Further restricting analyses by sex revealed no additional insights for IGFBP-1.

We also examined the relationship between insulin, $\mathrm{C}$ peptide, IGFBP-1, and obesity (BMI or waist-hip ratio (WHR), which are factors related to colorectal adenomas, CRC and insulin resistance (Table 4). In general, both insulin and C-peptide showed strong negative correlations with IGFBP-1. Both insulin and C-peptide showed highly significant positive correlations with BMI and WHR. In addition, there was strong inverse correlation between IGFBP-1 and BMI $(\mathrm{r}=-0.49, \mathrm{p}=0.0001)$, and IGFBP-1 and WHR $(\mathrm{r}=-0.29, \mathrm{p}=0.0001)$ (Table 4). The associations for men and women were comparable. Among adenoma cases, no correlations were found for C-peptide, insulin or IGFBP-1 levels and either number of adenomas $(r=0.03, p=0.65$; $\mathrm{r}=0.004, \mathrm{p}=0.96 ; \mathrm{r}=0.06, \mathrm{p}=0.41$, respectively) or adenoma size $(r=-0.05, p=0.50 ; r=0.14, p=0.06 ; r=-0.02$, $\mathrm{p}=0.80$, respectively).

\section{Discussion and conclusion}

In this study, we evaluated the relationship between insulin, C-peptide and IGFBP-1 in relation to colorectal adenomas and low apoptosis. We found that elevated levels of insulin and $\mathrm{C}$-peptide predicted increased risk of adenomas in men and women, while elevated levels of IGFBP-1 reduced risk, particularly in men. The risk of adenomas increased with increasing concentrations of $\mathrm{C}$-peptide and insulin, and decreased with increasing concentrations of IGFBP-1. We also found that in overweight and obese individuals higher $\mathrm{C}$-peptide increased the risk of low apoptosis, particularly in men, whereas elevated IGFBP-1 levels were associated with a reduced risk of low apoptosis, an association that was stronger in men. These findings suggest that the mechanism by which these hormones increase risk of adenomas may reflect their anti-apoptotic properties.

Insulin is secreted as pro-insulin and subsequently cleaved into insulin and C-peptide. C-peptide is a marker of pancreatic insulin synthesis, and several epidemiologic studies have utilized C-peptide as an alternate biomarker to insulin because it has a longer half-life than insulin and therefore is more stable [28]. We found positive associations between insulin, C-peptide and adenomas, in both men and women. While these findings contrast with those by Yamaji et al., who found these associations only in men in a Japanese cohort [24], they confirm both our previous observations in an independent patient population [17], and in a recent report in which we found race/ethnicity differences for genes related to the IGF axis [29]. The 
Table 4 Correlations between insulin, C-peptide, IGFBP-1 and BMI or WHR

\begin{tabular}{|c|c|c|c|c|c|}
\hline & C-Pep & IGFBP-1 & Insulin & BMI & Waist/Hip \\
\hline C-Peptide & 1 & $-0.38(0.0001)$ & $0.64(0.0001)$ & $0.45(0.0001)$ & $0.43(0.0001)$ \\
\hline IGFBP1 & & 1 & $-0.36(0.0001)$ & $-0.49(0.0001)$ & $-0.29(0.0001)$ \\
\hline Insulin & & & 1 & $0.45(0.0001)$ & $0.30(0.0001)$ \\
\hline BMI & & & & 1 & $0.35(0.0001)$ \\
\hline \multirow[t]{3}{*}{ Waist/Hip } & & & & & 1 \\
\hline & & Men & & & \\
\hline & C-Pep & IGFBP-1 & Insulin & BMI & Waist/Hip \\
\hline C-Peptide & 1 & $-0.28(0.0001)$ & $0.59(0.0001)$ & $0.43(0.0001)$ & $0.41(0.0001)$ \\
\hline IGFBP1 & & 1 & $-0.36(0.0001)$ & $-0.38(0.0001)$ & $-0.10(0.14)$ \\
\hline Insulin & & & 1 & $0.42(0.0001)$ & $0.28(0.002)$ \\
\hline BMI & & & & 1 & $0.36(0.0001)$ \\
\hline \multirow[t]{3}{*}{ Waist/Hip } & & & & & 1 \\
\hline & & Women & & & \\
\hline & C-Pep & IGFBP-1 & Insulin & BMI & Waist/Hip \\
\hline C-Peptide & 1 & $-0.43(0.0001)$ & $0.69(0.0001)$ & $0.46(0.0001)$ & $0.51(0.0001)$ \\
\hline IGFBP1 & & 1 & $-0.36(0.0001)$ & $-0.56(0.0001)$ & $-0.39(0.0001)$ \\
\hline Insulin & & & 1 & $0.48(0.0001)$ & $0.45(0.0001)$ \\
\hline BMI & & & & 1 & $0.43(0.0001)$ \\
\hline Waist/Hip & & & & & 1 \\
\hline
\end{tabular}

observed positive association between insulin, C-peptide and adenomas not only highlights the importance of the insulin-IGF pathway in risk of colorectal adenomas and cancer, but it also supports findings from previous studies [19-21,29-31]. Higher IGFBP-1 levels were associated with a reduced risk of adenomas. In these analyses, we did not observe significant differences between cases and controls for IGF-I; these findings are consistent with the hypothesis that higher levels of insulin and C-peptide, and lower levels of IGFBP-1 are the trigger points early in the disease development. Overall, these findings are in agreement with those of others [22], and support the hypothesis that biologically available IGF-1 circulating levels may be an etiologic factor in the formation of adenomas.

Only a limited number of studies have evaluated IGFBP-1 in relation to adenomas or cancer [22,32,33] but the results are inconsistent $[19,21,24,29,34]$. IGFBP1 , a member of the IGF binding protein family binds to IGF-I or IGF-II to regulate their bioavailability, in this way acting as a modulator of cellular proliferation and cell death [35]. IGFBP-1 can also inhibit metabolism of IGFs [36], and IGFBP-1 expression is negatively regulated by insulin [37]. Levels of circulating C-peptide and insulin inversely correlate with plasma IGFBP-1 levels [14], thus our findings support this observation. They however contrast with a recent report [32] in which high IGFBP-1 levels were inversely associated with colorectal cancer in women, since we only observed statistically significant associations in men. In a larger cohort, Le Marchand et al. also observed a significantly reduced adenoma risk with higher plasma IGFBP-1 levels [22]. Yamaji et al. reported similar associations in Japanese men [24]. Our first attempt to test for IGFBP-1 associations with low apoptosis, showed that overweight and obese individuals with higher C-peptide levels are more likely to have low apoptosis.

Epidemiologic studies suggest that lifestyle and dietary factors play an important role in the etiology of colorectal cancer. In particular, obesity is associated with increased risk of colon cancer, especially in men [38,39]. Men are also more likely to have higher waist-hip ratio, a condition that is associated with elevated levels of insulin and C-peptide [40,41]. Our findings show strong positive correlations between insulin or C-peptide and BMI or WHR among both men and women. In addition, there was a strong inverse association between IGFBP-1 and BMI or WHR. These findings suggest that metabolic characteristics associated with obesity and visceral adiposity may be important biomarkers of adenoma risk.

The major strengths of this study include availability of fasting blood specimens, detailed information on exposures and anthropometrics and ability to measure apoptosis in normal mucosal biopsies and test for correlations with circulating insulin, C-peptide or IGFBP-1 levels. There are some limitations of this study. Plasma samples were only available for one-time measures of 
insulin, C-peptide and IGFBP-1. However our findings are similar to other studies that used one-time measures of these analytes. Also, future studies should consider measuring insulin resistance based on the Homeostatic Model Assessment (HOMA).

In summary, we found significantly elevated levels of insulin and C-peptide in patients with adenoma when compared to adenoma-free controls. Elevated concentrations of IGFBP-1 reduced the risk for adenomas in men. These findings confirm our previous observations in an independent patient population and support the involvement of the insulin-IGF pathway in the etiology of colorectal carcinogenesis. Elevated C-peptide and insulin significantly predicted adenoma risk although $\mathrm{C}$-peptide appeared a stronger predictor of low apoptosis in overweight and obese men than women. The strong positive association between BMI and WHR, known colorectal cancer risk factors that are also related to hyperinsulinemia and the insulin-IGF axis, suggests an interplay between obesity, insulin-related factors and adenomas. Our findings suggest that the anti-apoptotic properties of these peptide hormones, particularly $\mathrm{C}$-peptide, may be the primary driver of associations with adenomas. Preventive measures to reduce obesity and closer monitoring of individuals may be beneficial to reducing adenoma and cancer risk.

\section{Competing interests}

The authors declared no competing interests.

\section{Authors' contributions}

TOK, RS and PKL conceived and designed the experiments. OO, LB and RH performed the experiments. TOK, PKL, CH and ACV analyzed and interpreted the data. TOK, ACV and CH wrote the paper. JAG performed statistical analyses. All authors have read and approved the final manuscript.

\section{Acknowledgements}

This project was supported in part by grants from the National Institutes of Health K01 CA93654, P30 DK 034987 and R01 CA 44684, P50 CA 106991, R01CA142983, R01CA142983-02S1

\section{Author details}

'Department of Obstetrics and Gynecology, and Program of Cancer Detection, Prevention and Control, for Duke University School of Medicine, Durham, North Carolina. ${ }^{2}$ Department of Medicine and Center for Gastrointestinal Biology \& Disease School of Medicine, University of North Carolina, Chapel Hill, North Carolina. ${ }^{3}$ Department of Cell and Molecular Physiology, School of Medicine, University of North Carolina, Chapel Hill, North Carolina.

Received: 26 April 2012 Accepted: 31 August 2012

Published: 5 September 2012

\section{References}

1. Takayama T, Katsuki S, Takahashi Y, Ohi M, Nojiri S, Sakamaki S, Kato J, Kogawa K, Miyake H, Niitsu Y: Aberrant crypt foci of the colon as precursors of adenoma and cancer. N Engl J Med 1998, 339:1277-1284.

2. Ferlay J, Shin H-R, Bray F, Forman D, Mathers C, Parkin DM: Estimates of worldwide burden of cancer in 2008: GLOBOCAN 2008. Int I Cancer 2010, 127:2893-2917.

3. Sridhar SS: Insulin-Insulin-like growth factor axis and colon cancer. J Clin Oncol 2009, 27:165-167.

4. Tran TT, Medline A, Bruce WR: Insulin promotion of colon tumors in rats. Cancer Epidemiol Biomarkers Prev 1996, 5:1013-1015.
5. Tran T, Naigamwalla D, Oprescu Al, Lam L, McKeown-Eyssen G, Bruce WR, Giacca A: Hyperinsulinemia, but not other factors associated with insulin resistance, acutely enhances colorectal epithelial proliferation in vivo. Endocrinology 2006, 147:1830-1837.

6. Giovannucci E: Insulin, insulin-like growth factors and colon cancer: a review of the evidence. J Nutr 2001, 131(11 Suppl):3109S-3120S.

7. Koenuma M, Yamori T, Tsuruo T: Insulin and insulin-like growth factor 1 stimulate proliferation of metastatic variants of colon carcinoma 26. Jph J Cancer Res 1989, 80:51-58.

8. Braulke T, Tippmer S, Neher E, von Figura K: Regulation of the mannose 6- phosphate/IGF II receptor expression at the cell surface by mannose 6-phosphate, insulin like growth factors and epidermal growth factor. EMBO J 1989, 8:681-686.

9. Le Roith D, Parrizas M, Blakesley VA: The insulin-like growth factor-I receptor and apoptosis. Implications for the aging progress. Endocrine 1997, 7:103-105.

10. Pandini G, Frasca F, Mineo R, Sciacca L, Vigneri R, Belfiore A: Insulin/insulinlike growth factor I hybrid receptors have different biological characteristics depending on the insulin receptor isoform involved. J Biol Chem 2002, 277:39684-39695.

11. Belfiore A, Frasca F, Pandini G, Sciacca L, Vigneri R: Insulin receptor isoforms and insulin receptor/insulin-like growth factor receptor hybrids in physiology and disease. Endocr Rev 2009, 30:586-623.

12. Kaaks R, Lukanova A: Energy balance and cancer: the role of insulin and insulin-like growth factor-I. Proc Nutr Soc 2001, 60:91-106.

13. Scharf J, Ramadori G, Braulke T, Hartmann H: Synthesis of insulin-like growth factor binding proteins and of the acid-labile subunit in primary cultures of rat hepatocytes, of Kupffer cells, and in cocultures: regulation by insulin, insulinlike growth factor, and growth hormone. Hepatology 1996, 23:818-827.

14. Katz LE, Jawad AF, Ganesh J, Abraham M, Murphy K, Lipman TH: Fasting c-peptide and insulin-like growth factor-binding protein-1 levels help to distinguish childhood type 1 and type 2 diabetes at diagnosis. Pediatr Diabetes 2007, 8:53-59.

15. Suikkari AM, Koivisto VA, Rutanen EM, Yki-Jarvinen H, Karonen SL, Seppala $\mathrm{M}$ : Insulin regulates the serum levels of low molecular weight insulin-like growth factor-binding protein. J Clin Endocrinol Metab 1988, 66:266-272.

16. Sato Y, Chen Z, Miyazaki K: Strong suppression of tumor growth by insulin-like growth factor-binding protein-related protein 1/tumorderived cell adhesion factor/mac25. Cancer Sci 2007, 98:1055-1063.

17. Keku TO, Lund PK, Galanko J, Simmons JG, Woosley JT, Sandler RS: Insulin resistance, apoptosis, and colorectal adenoma risk. Cancer Epidemiol Biomarkers Prev 2005, 14:2076-2081.

18. Keku TO, Sandler RS, Simmons JG, Galanko J, Woosley JT, Proffitt M, Omofoye O, McDoom M, Lund PK: Local IGFBP-3 mRNA expression, apoptosis and risk of colorectal adenomas. BMC Cancer 2008, 8:143.

19. Jenab M, Riboli E, Cleveland RJ, Norat T, Rinaldi S, Nieters A, Biessy C, Tjonneland A, Olsen A, Overvad K, Gronbaek H, Clavel-Chapelon F, BoutronRuault MC, Linseisen J, Boeing H, Pischon T, Trichopoulos D, Oikonomou E, Trichopoulou A, Panico S, Vineis P, Berrino F, Tumino R, Masala G, Peters PH, van Gils $\mathrm{CH}$, Bueno-de-Mesquita HB, Ocke MC, Lund E, Mendez MA, Tormo MJ, Barricarte A, Martinez-Garcia C, Dorronsoro M, Quiros JR, Hallmans G, Palmqvist R, Berglund G, Manjer J, Key T, Allen NE, Bingham S, Khaw KT, Cust A, Kaaks R: Serum C-peptide, IGFBP-1 and IGFBP-2 and risk of colon and rectal cancers in the European Prospective Investigation into Cancer and Nutrition. Int I Cancer 2007, 121:368-376.

20. Schoen RE, Weissfeld JL, Kuller LH, Thaete FL, Evans RW, Hayes RB, Rosen CJ: Insulin-like growth factor-I and insulin are associated with the presence and advancement of adenomatous polyps. Gastroenterology 2005, 129:464-475.

21. Wei EK, Ma J, Pollak MN, Rifai N, Fuchs CS, Hankinson SE, Giovannucci E: C-peptide, insulin-like growth factor binding protein-1, glycosylated hemoglobin, and the risk of distal colorectal adenoma in women. Cancer Epidemiol Biomarkers Prev 2006, 15:750-755.

22. Le Marchand L, Wang H, Rinaldi S, Kaaks R, Vogt TM, Yokochi L, Decker R: Associations of plasma C-peptide and IGFBP-1 levels with risk of colorectal adenoma in a multiethnic population. Cancer Epidemiol Biomarkers Prev 2010, 19:1471-1477.

23. Tsilidis KK, Brancati FL, Pollak MN, Rifai N, Clipp SL, Hoffman-Bolton J, Helzlsouer KJ, Platz EA: Metabolic syndrome components and colorectal adenoma in the CLUE II cohort. Cancer Causes Control 2010, 21:1-10. 
24. Yamaji T, Iwasaki M, Sasazuki S, Tsugane S: Gender difference in the association of insulin and the insulin-like growth factor axis with colorectal neoplasia. Int J Obesity (London) 2012, 36:440-447.

25. Ransohoff DF, Martin C, Wiggins WS, Hitt BA, Keku TO, Galanko JA, Sandler $\mathrm{RS}$ : Assessment of serum proteomics to detect large colon adenomas. Cancer Epidemiol Biomarkers Prev 2008, 17:2188-2193.

26. Vinikoor LC, Schroeder JC, Millikan RC, Satia JA, Martin CF, Ibrahim J, Galanko JA, Sandler RS: Consumption of trans-fatty acid and its association with colorectal adenomas. Am J Epidemiol 2008, 168:289-297.

27. Subar AF, Thompson FE, Kipnis V, Midthune D, Hurwitz P, McNutt S, McIntosh A, Rosenfeld S: Comparative validation of the Block, Willett, and National Cancer Institute food frequency questionnaires: the Eating at America's Table Study. Am J Epidemiol 2001, 154:1089-1099.

28. Hovorka R, Jones RH: How to measure insulin secretion. Diabetes Metab Rev 1994, 10:91-117.

29. Keku T, Vidal A, Oliver S, Hoyo C, Hall IJ, Omofoye S, McDoom M, Worly K, Galanko J, Sandler RS, Millikan R: Genetics variants in IGF-I, IGF-II, IGFBP-3, and adiponectin genes and colon cancer risk in African American and Whites. Cancer Causes Control 2012, 23:1127-1138.

30. Palmqvist R, Stattin P, Rinaldi S, Biessy C, Stenling R, Riboli E, Hallmans G, Kaaks R: Plasma insulin, IGF-binding proteins- 1 and -2 and risk of colorectal cancer: a prospective study in northern Sweden. Int J Cancer 2003, 107:89-93.

31. Ma J, Giovannucci E, Pollak M, Leavitt A, Tao Y, Gaziano JM, Stampfer MJ: A prospective study of plasma C-peptide and colorectal cancer risk in men. J Natl Cancer Inst 2004, 96:546-553.

32. Kaaks R, Toniolo P, Akhmedkhanov A, Lukanova A, Biessy C, Dechaud H, Rinaldi S, Zeleniuch-Jacquotte A, Shore RE, Riboli E: Serum C-peptide, insulin-like growth factor (IGF)-I, IGF-binding proteins, and colorectal cancer risk in women. J Natl Cancer Inst 2000, 92:1592-1600.

33. Wei EK, Ma J, Pollak MN, Rifai N, Fuchs CS, Hankinson SE, Giovannucci E: A prospective study of $C$-peptide, insulin-like growth factor-l, insulin-like growth factor binding protein-1, and the risk of colorectal cancer in women. Cancer Epidemiol Biomarkers Prev 2005, 14:850-855

34. Jacobs ET, Martinez ME, Alberts DS, Ashbeck EL, Gapstur SM, Lance P, Thompson PA: Plasma insulin-like growth factor I is inversely associated with colorectal adenoma recurrence: a novel hypothesis. Cancer Epidemiol Biomarkers Prev 2008, 17:300-305.

35. Collett-Solberg PF, Cohen P: Genetics, chemistry, and function of the IGF/ IGFBP system. Endocrine 2000, 12:121-136.

36. Murphy LJ, Rajkumar K, Molnar P: Phenotypic manifestations of insulin-like growth factor binding protein-1 (IGFBP-1) and IGFBP-3 overexpression in transgenic mice. Prog Growth Factor Res 1995, 6:425-432.

37. LeRoith D, Yakar S: Mechanisms of disease: metabolic effects of growth hormone and insulin-like growth factor 1. Nat Clin Pract Endocrinol Metab 2007, 3:302-310.

38. Giovannucci E: Metabolic syndrome, hyperinsulinemia, and colon cancer: a review. Am J Clin Nutr 2007, 86:5836-\$842

39. Pischon $\mathrm{T}$, Lahmann $\mathrm{PH}$, Boeing $\mathrm{H}$, Friedenreich $\mathrm{C}$, Norat $\mathrm{T}$, Tjonneland $\mathrm{A}$, Halkjaer J, Overvad K, Clavel-Chapelon F, Boutron-Ruault MC, Guernec G, Bergmann MM, Linseisen J, Becker N, Trichopoulou A, Trichopoulos D, Sier $S$, Palli D, Tumino R, Vineis P, Panico S, Peeters PH, Bueno-de-Mesquita HB, Boshuizen HC, Van Guelpen B, Palmqvist R, Berglund G, Gonzalez CA, Dorronsoro M, Barricarte A, Navarro C, Martinez C, Quiros JR, Roddam A, Allen N, Bingham S, Khaw KT, Ferrari P, Kaaks R, Slimani N, Riboli E: Body size and risk of colon and rectal cancer in the European Prospective Investigation Into Cancer and Nutrition (EPIC). J Natl Cancer Inst 2006, 98:920-931.

40. Hanley AJ, McKeown-Eyssen G, Harris SB, Hegele RA, Wolever TM, Kwan J, Zinman B: Cross-sectional and prospective associations between abdominal adiposity and proinsulin concentration. J Clin Endocrinol Metab 2002, 87:77-83.

41. Okosun IS, Chandra KM, Boev A, Boltri JM, Choi ST, Parish DC, Dever GE: Abdominal adiposity in U.S. adults: prevalence and trends, 1960-2000. Prev Med 2004, 39:197-206.

\section{Submit your next manuscript to BioMed Central and take full advantage of:}

- Convenient online submission

- Thorough peer review

- No space constraints or color figure charges

- Immediate publication on acceptance

- Inclusion in PubMed, CAS, Scopus and Google Scholar

- Research which is freely available for redistribution 